\title{
Being Survive During Pandemic: The Analysis Character Strength and Health Related Quality of Life in Covid- 19 Survivors
}

\author{
Umniyah Saleh \\ Universitas Hasanuddin \\ Psychology Department, Medical \\ Faculty \\ Email: umniyah.saleh@unhas.ac.id
}

\author{
Nur Faizah \\ Universitas Hasanuddin \\ Psychology Department, Medical \\ Faculty \\ Email: nurfaaiizaahh27@gmail.com
}

\author{
Nur Fajar Alfitra \\ Universitas Hasanuddin \\ Psychology Department, Medical \\ Faculty \\ Email: alfitra.nurfajar@gmail.com
}

\author{
S. Nurul Azizah \\ Universitas Hasanuddin \\ Psychology Department, Medical \\ Faculty \\ Email: \\ azizahsn19c@student.unhas.ac.id \\ Haiqal Aliftiansyah Ma'rufi \\ Universitas Hasanuddin \\ Psychology Department, Medical \\ Faculty \\ Email: haiqalaliftianysh@gmail.com
}

\author{
Muh Ikhsan Rahmat \\ Universitas Hasanuddin \\ Psychology Department, Medical \\ Faculty \\ Email: muhikhsanr4II@gmail.com
}

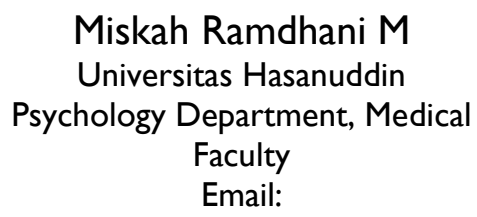

miskahrmachmoed@gmail.com

\begin{abstract}
This research focuses on exploring the characters strength among covid-19 survivors regarding to their HRQOL' level. This research used a quantitative method with a cross-sectional survey design, with WHOQOL-BREF scale and VIA Strength Classification System as measurement tools. The sampling method was purposive sampling, with the criteria of the respondent are have been infected by the SARSCov-2 and living in Makassar City. There are 52 respondents were selected for the analysis process. The present study found that hope is one of the influential factors on HRQOL based on the rank order. The hope rank significantly increased along with the level of HRQOL. Thus, the development of rank in hope characters, it can be concluded that hope is an important character for covid-19 survivors in increasing their Health-Related Quality of Life (HRQOL).
\end{abstract}

Keywords: Character Strength, Health Related Quality of Life, Covid 19 Survivors

Received II Oktober 202I/Accepted I0 December 202I @Author all rights reserved

\section{Introduction}

The covid-19 pandemic has changed so many aspects of people's lives and not limited only to their social activity but also psychological state. A certain situation such as lockdown, working and school from home, and self-isolation can cause several mental issues. Thus, including feeling bored, mood change, anxiety, panic state, and even depression (Bao, Sun, 
Meng, Shi \& Lu, 2020; Chew, Wei, Vasoo, Chua \& Sim, 2020; Irawan, Dwisona \& Lestari, 2020; Xu, Li, Tian, Li \& Kong, 2020). People’ psychological state might also be worsened with unvalidated news and not trusted information that related to conspiration about Covid-19 during pandemic situations (Brooks, et al, 2020; Banerjee \& Sathyanarayana, 2020; Swire-Thompson \& Lazer, 2020). It can cause more people to be in panic and anxiety about the current situation.

Besides those issues, the pandemic situation also affects people' perspective about their health status and their effort to fully function. People' perspective is related to their health and effort to be healthy also known as Health-Related Quality of Life (HRQOL). A situation such as schools' Lockdown and self-isolation that cause distress, especially among children and adolescents can decrease their Health-Related Quality of Life (Chen, Chen, O"Brien \& Latner, 2020; Riiser, Helseth, Haraldstad, Torbjornsen \& Richardsen, 2020). In addition, people that got infected by SARS-Cov-19 tend to have a low-level Health Related Quality of Life. The main reason is that they are experiencing an uncomfortable situation, both physical and psychological, and cannot function fully in society (Chen, Li, Gong, Zhang \& Kun Li, 2020; Ping, Zheng, Niu, Guo, Zhang, Yang \& Shi, 2020; Nguyen, et al., 2020).

Health Related Quality of Life or HRQOL can be defined as subjective evaluation about health status, disease history, factors that can affect individual's health, and attempt to achieve optimal life to fulfilled life's goals (Cummins, Lau, \& Stokes, 2004; Ferrans, Zerwick, Wilbur \& Larson, 2005; Karimi \& Brazier, 2016). Furthermore, the evaluation established from a physical and mental condition, the correlation between both physical and mental, and other aspects that can affect an individual's health such as social support and socialeconomic status (The WHOQOL Group, 1998; Oksuz \& Malhan, 2006). It can be said that HRQOL is established and might affect an individual's well-being (Smith, 2000; Maartje de Wit, et.al, 2008; Kanauchi, Kubo, Kanauchi \& Saito, 2008).

As self-evaluation, HRQOL can be affected by certain traits and characteristics that individuals nurture (Ferrans, et al, 2005; Bonacchi, Miccinesi, Guazzini, et al, 2012; Ho, Li, Cheung, et al, 202I). The reason lies in the way characteristics or traits function as a base that influences people's behaviour and attributes such as beliefs, attitudes, and personality. 
Thus, differentiation in HRQOL can happen among people because of diversity in traits or characters.

Character strength such as "hope" can increase and might even decrease the level of HRQOL. Several studies explains that "hope" is the essential factor that can positively contribute to the level of HRQOL (Munoz, Hellman, Buster, Robbins \& Carrol, 20I7; Ho, Li \& Cheung, 2019; Jiang, Ren, Jiang, et al, 202I). As one of the character strengths, "hope" plays a significant role in developing HRQOL since it can influence the self-esteem' degree and depressive symptoms (Ho, Li, Cheung, et al, 202I). Besides "hope”, other character strengths also play an essential role in developing HRQOL. Cherry, et al., (2016) found that "optimism" and "hope" are the protective factor of natural disaster survivors and they can help them to stay mentally healthy. In addition, "gratitude" also has a similar effect on people' psychological state (Disabato, et al., 2017).

As individual uniqueness, character strength can be defined as an important aspect that can help people to become better since it focuses on the process and mechanism of the people' journey. It can be said that character strength is the main psychological ingredient to achieve an individual's virtues (Peterson \& Seligman, 2004). Character strength-based on Peterson and Seligman (2004) consists of six core virtues which have four to five characters, that is wisdom \& knowledge, courage, humanity, justice, temperance, and transcendence.

Although, several studies already explain the contribution of characters strengths towards HRQOL, the explanation about the position (or the rank) of each character's strength is still limited. Furthermore, studies related to HRQOL during pandemics much more emphasized the lower degree of HRQOL since it is related to depression or discomfort experience perceived by the patients (Nguyen, et al., 2020; Ping, Zheng, Niu, Guo, Zhang, Yang \& Shi, 2020).

Based on the explanation above, the present study focuses on exploring the characters strength among covid-19 survivors regarding to their HRQOL' level. The strong connection between characters strengths such as hope, gratitude and optimism towards HRQOL will 
be assumed as one of the important characters that can be found in a certain level of HRQOL.

\section{Method}

Procedure and Participant

The present study used a quantitative method with a cross-sectional survey design where the data was collected thru questionnaires directly from the participant (Creswell, 2006). The survey was conducted using an online platform (google form) and was shared through social media for 6 weeks. The sampling method in this present study was purposive sampling, with the criteria of the respondent are the survivors or have been infected by the SARS-Cov-2.

A total of 55 covid-19 survivors completed the online survey. Thus, the survivors are residence in Makassar City, Indonesia. All respondents complete an online informed consent before proceeding into the next step, that is the online survey. The informed consent was given in the first part of survey along with it all related information regarding with the research. From the total of 55 respondents, only 52 was selected for the analysis process since some of them is not passed in the cleaning data process. Among the respondent there is $38 \%$ male $(n=20)$ and female $62 \%(n=32)$.

\section{Measurement}

The Health-Related Quality of Life was measured using the WHOQOL-BREF scale which was developed by World Health Organization and translated into Bahasa by Nadia Syawalani (2019). The scale consists of 26 items that measure four aspects of healthiness that is physical, psychological, social support, and environment. The item response was presented in Likert-Scale and the response differ in every part of scale. At the first part, the response was range from "very bad" to "very good". The second part and the third part' responses were range from "not at all" to "fully". The fourth part' responses were range from "very dissatisfied" to "very satisfied". At the last part of scale, the response was range from "rarely" to "frequently". The example of item was (I) How would you rate your quality of 
life?, (2) How much do you enjoy life?, (3) How satisfied are you with your sleep?. The Cronbach alpha of WHOQOL-BREF was .845.

Character Strength was measured using the Value-In-Action (VIA) Strength Classification System. The version of VIA that was used in this study was VIA-72 with Bahasa Indonesia. The scale consists of 72 items that measure 24 characters from six core virtues. There are five different responses available on each item and it was presented in Likert-Scale. The responses were range from "very not like me" to "very like me". The example of item was (I) I often stood up against strong opponent, (2) I gave everyone an equal chance, (3) I am an original thinker. Originally, the Cronbach alpha of VIA-72 was above .60 on every character.

\section{Data Analysis}

The data from 52 respondents were statistically analysed using descriptive statistical analysis. The mean (M) and standard deviation (SD) became the focus on the rank system and stated the level of the intended variable. The descriptive analysis was conducted using SPSS ver.28 for mac and Microsoft Excel.

\section{Result}

Descriptive statistics for character strength were ordered for the whole sample presented in Table I, where kindness $(M=3.96)$ became the highest characters that covid-19 survivors have. The mean ranges from 3.12 (love of learning) to 3.96 (kindness) for the whole sample of covid-19 survivors. Thus, it can be said that the whole sample has a moderate mean for character strength.

All character strengths were rank ordered by HRQOL level (Table. 2) to see any rank differences between low $(N=17)$, moderate $(N=16)$, and high level $(N=19)$ of HRQOL. The differentiation on HRQOL level was obtained by calculating mean and standard deviation into normalization formula. In the low level of HRQOL kindness $(M=3.90)$ was the top characters strength. It is quite difference with moderate level were gratitude $(M=3.98)$ is the top character strength. As for the high level of HRQOL, hope ( $M=4.23)$ was the top characters strength. Although hope is number one, the top character strength in low and 
moderate level that is kindness and gratitude still in top 10 of highest characters in the high level of HRQOL Furthermore, the hope character also appears in top 10 of every level of HRQOL it is quite the same with spirituality that also showed in top 10 highest characters in every level of HRQOL.

Table I

Character strength rank-order across the whole sample

\begin{tabular}{clc}
\hline Rank & Whole Sample (N=52) & Mean \\
\hline 1 & Kindness & 3.96 \\
2 & Fairness & 3.93 \\
3 & Gratitude & 3.92 \\
4 & Teamwork & 3.90 \\
5 & Perseverance & 3.88 \\
6 & Hope & 3.87 \\
7 & Judgement & 3.85 \\
8 & Prudence & 3.83 \\
9 & Spirituality & 3.81 \\
10 & Leadership & 3.78 \\
11 & Social-Intelligence & 3.76 \\
12 & Curiosity & 3.71 \\
13 & Humour & 3.71 \\
14 & Appreciation of Beauty & 3.68 \\
15 & Forgiveness & 3.66 \\
16 & Honesty & 3.66 \\
17 & Zest & 3.56 \\
18 & Bravery & 3.54 \\
19 & Love & 3.48 \\
20 & Creativity & 3.31 \\
21 & Humility & 3.27 \\
22 & Perspective & 3.17 \\
23 & Self-Regulation & 3.17 \\
24 & Love of Learning & 3.12 \\
\hline
\end{tabular}

Note: $N=52$ (male=20, female=32); Mean= the average value of total score. 
Table 2

Character strength rank-ordered by the level of $\mathrm{HRQOL}$

\begin{tabular}{|c|c|c|c|c|c|c|c|c|}
\hline Rank & $\begin{array}{l}\text { Low HRQOL } \\
\qquad(N=17)\end{array}$ & Mean & Rank & $\begin{array}{l}\text { Moderate } \\
\text { HRQOL } \\
(\mathrm{N}=16)\end{array}$ & Mean & Rank & $\begin{array}{l}\text { High HRQOL } \\
\qquad(\mathrm{N}=19)\end{array}$ & Mean \\
\hline I & Kindness & 3.90 & I & Gratitude & 3.98 & I & Hope & 4.23 \\
\hline 2 & Judgement & 3.90 & 2 & Fairness & 3.96 & 2 & $\begin{array}{l}\text { Social- } \\
\text { Intelligence }\end{array}$ & 4.14 \\
\hline 3 & Fairness & 3.80 & 3 & Prudence & 3.94 & 3 & Teamwork & 4.12 \\
\hline 4 & Perseverance & 3.76 & 4 & Kindness & 3.94 & 4 & Perseverance & 4.11 \\
\hline 5 & Gratitude & 3.75 & 5 & Teamwork & 3.92 & 5 & Gratitude & 4.02 \\
\hline 6 & Prudence & 3.73 & 6 & Spirituality & 3.81 & 6 & Kindness & 4.02 \\
\hline 7 & Teamwork & 3.65 & 7 & Hope & 3.79 & 7 & Fairness & 4.02 \\
\hline 8 & Leadership & 3.65 & 8 & Forgiveness & 3.75 & 8 & Humour & 4.00 \\
\hline 9 & Spirituality & 3.61 & 9 & Perseverance & 3.73 & 9 & Spirituality & 3.98 \\
\hline 10 & Honesty & 3.61 & 10 & Curiosity & 3.73 & 10 & Leadership & 3.93 \\
\hline 11 & Forgiveness & 3.61 & 11 & Leadership & 3.73 & II & Curiosity & 3.91 \\
\hline 12 & Hope & 3.55 & 12 & $\begin{array}{l}\text { Appreciation } \\
\text { of Beauty }\end{array}$ & 3.73 & 12 & Judgement & 3.91 \\
\hline 13 & $\begin{array}{l}\text { Appreciation } \\
\text { of Beauty }\end{array}$ & 3.49 & 13 & Judgement & 3.73 & 13 & Love & 3.84 \\
\hline 14 & Curiosity & 3.45 & 14 & Zest & 3.65 & 14 & Prudence & 3.84 \\
\hline 15 & Humour & 3.45 & 15 & $\begin{array}{l}\text { Social- } \\
\text { Intelligence }\end{array}$ & 3.65 & 15 & $\begin{array}{l}\text { Appreciation } \\
\text { of Beauty }\end{array}$ & 3.81 \\
\hline 16 & Bravery & 3.43 & 16 & Humour & 3.63 & 16 & Zest & 3.79 \\
\hline 17 & $\begin{array}{l}\text { Social- } \\
\text { Intelligence }\end{array}$ & 3.43 & 17 & Honesty & 3.58 & 17 & Honesty & 3.77 \\
\hline 18 & Humility & 3.27 & 18 & Bravery & 3.52 & 18 & Bravery & 3.67 \\
\hline 19 & $\begin{array}{l}\text { Self- } \\
\text { Regulation }\end{array}$ & 3.27 & 19 & Love & 3.46 & 19 & Forgiveness & 3.63 \\
\hline 20 & Zest & 3.22 & 20 & Creativity & 3.19 & 20 & Creativity & 3.54 \\
\hline 21 & Perspective & 3.18 & 21 & $\begin{array}{l}\text { Self- } \\
\text { Regulation }\end{array}$ & 3.10 & 21 & Humility & 3.42 \\
\hline
\end{tabular}


Table 2

Character strength rank-ordered by the level of HRQOL

\begin{tabular}{|c|c|c|c|c|c|c|c|c|}
\hline Rank & $\begin{array}{c}\text { Low HRQOL } \\
\qquad(\mathrm{N}=\mid 7)\end{array}$ & Mean & Rank & $\begin{array}{c}\text { Moderate } \\
\text { HRQOL } \\
(\mathrm{N}=16)\end{array}$ & Mean & Rank & $\begin{array}{l}\text { High HRQOL } \\
\qquad(\mathrm{N}=19)\end{array}$ & Mean \\
\hline 22 & Creativity & 3.16 & 22 & $\begin{array}{l}\text { Love of } \\
\text { Learning }\end{array}$ & 3.10 & 22 & Perspective & 3.30 \\
\hline 23 & $\begin{array}{l}\text { Love of } \\
\text { Learning }\end{array}$ & 3.12 & 23 & Humility & 3.08 & 23 & $\begin{array}{l}\text { Love of } \\
\text { Learning }\end{array}$ & 3.14 \\
\hline 24 & Love & 3.10 & 24 & Perspective & 3.02 & 24 & $\begin{array}{l}\text { Self- } \\
\text { Regulation }\end{array}$ & 3.12 \\
\hline
\end{tabular}

Note: $N=52$ (male=20, female=32); Mean= the average value of total score.

\section{Discussion}

The present study was aimed to picture the characters strength among covid-19 survivors with the level of HRQOL accounted. Approximately 52 survivors in Makassar city have participated in this study. Based on their HRQOL level, there were 19 survivors have a high level of HRQOL, 16 survivors have moderate level HRQOL, and 17 survivors have lowlevel HRQOL.

The whole sample' rank showed ten essential character strengths that covid-19 survivors have, that is kindness, fairness, gratitude, teamwork, perseverance, hope, judgement, prudence, spirituality, and leadership, respectively. Among those characters strength, some of the characters such as gratitude, perseverance, hope, and spirituality were mentioned in previous studies as the factor that correlates highly with HRQOL (Disabato et.al, 2017; Munoz et.al, 2017; Ho, Li \& Cheung, 2019). As the characters that related to the thankfulness and appreciate positive aspect in life, gratitude can elevate people' well-being (Wood, Froh, \& Geraghty, 2010) which can establish a better perception of their health of HRQOL. The same effect is also shown with character hope, zest, perseverance and appreciation of beauty (Sharkey et al, 2017; Traino, et al, 2019; Smedema, 2020; Smedama \& Bhattarai, 202I). The uniqueness of character spirituality where it becomes the essential 
belief for people also significantly affect the people HRQOL, both physically and mentally (Krupski, et al, 2005; Davison \& Jhangri, 2010).

The differences in HRQOL shows a diverse rank of character strength. The present study found that character hope' rank increase at the same time the level of HRQOL increase. The hope character increase from rank number 12 in a low level of HRQOL to rank number $I$ in a high level of HRQOL. Thus, it can be said that hope is essential in increasing the level of HRQOL.

The characters hope is the key component and important in people's life and health. The reason is lies in the people belief of good result in the future, especially during uncertain time when they have an illness (Dufault, 1985; Long, Kim, Chen, Wilson, Worthington \&, VandeWeele, 2020; Balen \& Merluzzi, 2021). Furthermore, hope as a driving force is also important in recovery situations, especially in patients. Thus, when the patient has high hope about their health and recovery situation the HRQOL also increase. It can be said that patient's level of hope predicts their HRQOL (Rustøen, Cooper, Miaskowski, 2010). The result of the present study supports the previous study where characters hope can become a factor that can affect the level of HRQOL (Munoz, Hellman, Buster, Robbins \& Carrol, 2017). This present study also can give support to the previous study that found hope characters is important in life development and life quality, besides other characters such as gratitude, appreciation of beauty and zest (Ho, Li \& Cheung, 2019; Smedema \& Bhattarai, 2021

\section{Conclusion}

The present study found that hope is one of the influential factors on HRQOL based on the rank order. The hope rank significantly increased along with the level of HRQOL. In the low level of HRQOL, Hope rank is 12 with a mean of 3.55 and increased to rank 7 with a mean of 3.79 in the moderate level of HRQOL. Hope became number I in the high level of HRQOL with a mean of 4.23. Thus, based on the development of rank in hope characters, it can be concluded that hope is an important character for covid-19 survivors in increasing their Health-Related Quality of Life (HRQOL). 


\section{References}

Balen, N. S., \& Merluzzi, T. V. (202I). Hope, uncertainty, and control: A theoretical integration in the context of serious illness. Patient Education and Counseling, 104(II), 2622-2627.

Banerjee, D., \& Sathyanarayana Rao, T. S. (2020). Psychology of misinformation and the media: Insights from the COVID-19 pandemic. Indian J Soc Psychiatry [serial online] 2020 [cited 2021 Dec 6];36, Suppl SI:I3I-7. Available from: https://www.indjsp.org/text.asp?2020/36/5//31/297/32,

Bao, Y., Sun, Y., Meng, S., Shi, J., \& Lu, L. (2020). 2019-nCoV epidemic: address mental health care to empower society. The Lancet, 395(I0224), e37-e38.

Bonacchi, A., Miccinesi, G., Guazzini, M., Rossi, A., Bacci, S., Toccafondi, A., ... \& Rosselli, M. (20I2). Temperament and character traits associated with health-related quality of life in cancer patients. Tumori Journal, 98(3), 377-384.

Brooks, S. K., Webster, R. K., Smith, L. E., Woodland, L., Wessely, S., Greenberg, N., \& Rubin, G. J. (2020). The psychological impact of quarantine and how to reduce it: rapid review of the evidence. The lancet, 395(I0227), 912-920.

Chen, K. Y., Li, T., Gong, F., Zhang, J. S., \& Li, X. K. (2020). Predictors of health-related quality of life and influencing factors for COVID-19 patients, a follow-up at one month. Frontiers in Psychiatry, II, 668.

Chen, C. Y., Chen, I. H., O’Brien, K. S., Latner, J. D., \& Lin, C. Y. (202I). Psychological distress and internet-related behaviors between schoolchildren with and without overweight during the COVID-19 outbreak. International Journal of Obesity, 45(3), 677686.

Cherry, K. E., Sampson, L., Galea, S., Marks, L. D., Nezat, P. F., Baudoin, K. H., \& Lyon, B. A. (2017). Optimism and hope after multiple disasters: Relationships to health-related quality of life. Journal of loss and trauma, 22(I), 6I-76.

Chew, Q. H., Wei, K. C., Vasoo, S., Chua, H. C., \& Sim, K. (2020). Narrative synthesis of psychological and coping responses towards emerging infectious disease outbreaks in the general population: practical considerations for the COVID-19 pandemic. Singapore medical journal, 6 I (7), 350.

Creswell, J. W. (2016). Research design. Qualitative and Quantitative Approach. Thousand Oaks: Sage Publications.

Cummins, R. A., Lau, A. L., \& Stokes, M. (2004). HRQOL and subjective well-being: Noncomplementary forms of outcome measurement. Expert Review of Pharmacoeconomics \& Outcomes Research, 4(4), 413-420.

Dufault K, \& Martocchio B. C. (1985). Hope: its spheres and dimensions. Nurs Clin North Am, 20, 379-91. 
Davison, N.S \& Jhangri, G.S. (2010). Existential and Religious Dimensions of Spirituality and Their Relationship with Health-Related Quality of Life in Chronic Kidney Disease. Clin J Am Soc Nephrol. 5(II), 1969-1976. doi: 10.2215/CJN.01890310.

CJASN November 2010, 5 (II) 1969-1976; DOI: https://doi.org/10.2215/CJN.01890310

Disabato, D. J., Kashdan, T. B., Short, J. L., \& Jarden, A. (2017). What predicts positive life events that influence the course of depression? A longitudinal examination of gratitude and meaning in life. Cognitive Therapy and Research, 4 I (3), 444-458.

Ferrans, C. E., Zerwic, J. J., Larson, J. J., \& Wilbur, J. E. (2005). Conceptual model of healthrelated quality of life. Journal of Nursing Scholarship, 37(4), 336-342.

Ho, L. L. K., Li, W. H. C., Cheung, A. T., Ho, E. K. Y., Lam, K. K. W., Chiu, S. Y., ... \& Chung, J. O. K. (202I). Relationships among hope, psychological well-being and health-related quality of life in childhood cancer survivors. Journal of health psychology, 26(10), I5281537.

Irawan, A. W., Dwisona, D., \& Lestari, M. (2020). Psychological impacts of students on online learning during the pandemic COVID-19. KONSELI: Jurnal Bimbingan dan Konseling (E-Journal), 7(I), 53-60.

Jiang, C., Ren, Q., Jiang, S. et al. (202I). Association between objective and subjective deprivation and health-related quality of life among Chinese adolescents: Hope as a moderator. Child Ind Res 14, 24I7-2432 (202I). https://doi.org//0.1007/s|2187-02I$\underline{0985 I-y}$

Kanauchi, M., Kubo, A., Kanauchi, K., \& Saito, Y. (2008). Frailty, health-related quality of life and mental well-being in older adults with cardiometabolic risk factors. International journal of clinical practice, 62(9), |447-|45।.

Karimi, M., \& Brazier, J. (2016). Health, health-related quality of life, and quality of life: what is the difference?. Pharmacoeconomics, 34(7), 645-649.

Krupski, T. L., Kwan, L., Fink, A., Sonn, G. A., Maliski, S., \& Litwin, M. S. (2006). Spirituality influences health related quality of life in men with prostate cancer. Psycho-Oncology: Journal of the Psychological, Social and Behavioral Dimensions of Cancer, I5(2), I2I-I3I.

Long, K. N., Kim, E. S., Chen, Y., Wilson, M. F., Worthington Jr, E. L., \& VanderWeele, T. J. (2020). The role of Hope in subsequent health and well-being for older adults: An outcome-wide longitudinal approach. Global Epidemiology, 2, 100018.

Maartje de, Wit, Henriette A. Delemarre-van de Waal, Jan Alle Bokma, Krijn Haasnoot, Mieke C. Houdijk, Reinoud J. Gemke, Frank J. Snoek. (2008). Monitoring and discussing health-related quality of life in adolescents with type I diabetes improve psychosocial well-being. Diabetes Care, 3I(8), I52I-I526. DOI: $10.2337 / \mathrm{dc} 08-0394$

Munoz, R. T., Hellman, C. M., Buster, B., Robbins, A., Carroll, C., Kabbani, M., ... \& Fox, M. D. (2016). Life satisfaction, hope, and positive emotions as antecedents of health related quality of life among homeless individuals. International Journal of Applied Positive Psychology, I(I), 69-89. 
Nguyen, H.C., Nguyen, M.H., Do, B.N., Tran., C.Q., Nguyen, T.T., \& Pham, K.M. (2020). People with suspected covid-19 symptoms were more likely depressed and had lower health-related quality of life: The potential benefit of health literacy. Journal of Clinical Medicine, 9, 965. doi: $10.3390 / \mathrm{jcm} 9040965$.

Oksuz, E., \& Malhan, S. (2006). Compendium health related quality of life. Ankara: Baskent University.

Peterson, C \& Seligman, M.E. (2004). Character strengths and virtues: A handbook and classification. American Psychological Association; Oxford University.

Ping W, Zheng J, Niu X, Guo C, Zhang J, \& Yang H. (2020). Evaluation of health-related quality of life using EQ-5D in China during the COVID-19 pandemic. PLOS ONE 15(6): e0234850. https://doi.org/I0.137//journal.pone.0234850

Renaldi, N.S., (2019). Pemaknaan dukungan sosial dan health related quality of life pada survivor kanker serviks. Skripsi. (Tidak diterbitkan). Prodi Psikologi, Fakultas Kedokteran Universitas Hasanuddin.

Riiser, K., Helseth, S., Haraldstad, K., Torbjornsen, A., Richardsen. (2020). Adolescents' health literacy, health protective measures, and health-related quality of life during the Covid-19 pandemic. PLoS ONE 15(8): e0238I6I. https://doi. org/10.137I/journal.pone.0238161

Rustøen T, Cooper B, \& Miaskowski C. (2010). The importance of hope as a mediator of psychological distress and life satisfaction in a community sample of cancer patients. Cancer Nurs, 33, 258-67. doi: 10.1097/NCC.0b0 I 3e3 I8I d6fb6 I

Sharkey, C.M., Bakula, D.M.,Gamwell, K.L., MS, Mullins, A.J.,MS, Chaney, J.M., Mullins, L.L., (2017). The Role of Grit in College Student Health Care Management Skills and Health-Related Quality of Life, Journal of Pediatric Psychology, 42(9), 95296I, https://doi.org/10.1093/jpepsy/jsx073

Smedema, S. M., \& Bhattarai, M. (202I). The unique contribution of character strengths to quality of life in persons with multiple sclerosis. Rehabilitation Psychology, 66(I), 7686. https://doi.org//0.1037/rep0000363

Smedema, S.M. (2020). An analysis of the relationship of character strengths and quality of life in persons with multiple sclerosis. Qual Life Res, 29, 1259-1270. https://doi.org/10.1007/s I I 136-019-02397-I

Smith, A. (2000). Researching of quality-of-life pf older people: concepts, measures, and findings. Journal Center of Social Gerontology Working Paper, 7, 5-7.

Southwell, S., \& Gould, E. (2017). A randomised wait list controlled pre-post-follow-up trial of a gratitude diary with a distressed sample. The Journal of Positive Psychology, 12(6), 579-593.

The WHOQOL Group. (1998). The world health organization quality of life assessment (WHOQOL): development and general psychometric properties. Journal of Social, Science, and Medicine, 46(I2), I569-I585. 
Swire-Thompson B, \& Lazer D. (2020). Public health and online misinformation: Challenges and recommendations. Annual Review of Public Health. 4I, 433-45I. DOI: I0.I I46/annurev-publhealth-040 I I9-094 I27. PMID: 3 I 874069

Traino, K. A., Bakula, D. M., Sharkey, C. M., Roberts, C. M., Ruppe, N. M., Chaney, J. M., \& Mullins, L. L. (2019). The role of grit in health care management skills and healthrelated quality of life in college students with chronic medical conditions. Journal of Pediatric Nursing, 46, 72-77. doi:10.1016/j.pedn.2019.02.035

Wood, A. M., Froh, J. J., \& Geraghty, A. W. A. (2010). Gratitude and well-being: A review and theoretical integration. Clinical Psychology Review, 30(7), 890905. doi:10.1016/j.cpr.2010.03.005

Xu, Z., Li, S., Tian, S., Li, H., \& Kong, L. Q. (2020). Full spectrum of COVID-I 9 severity still being depicted. The Lancet, 395( I0228), 947-948. 